\title{
Health Care Associated Infections: Sources and Routes of Transmission
}

\author{
Hans Jørn Kolmos \\ Department of Clinical Microbiology, Odense University Hospital \\ Denmark
}

\section{Introduction}

Health care associated infections are infections that patients acquire, while they are in contact with the healthcare system. Contact includes all procedures associated with diagnostics, treatment, care, and rehabilitation. Health care associated infections were formerly called hospital or nosocomial infections. Hospitals still account for the vast majority of cases; however, for practical reasons the concept has been widened to comprise infections in all parts of the health care system, because a growing part of disease management takes place outside hospitals, e.g. in out patient clinics, nursing homes and general practice. The spectrum of health care associated infections ranges from simple common colds to life threatening sepsis with multidrug resistant organisms. With the above definition, around $10 \%$ of patients on average will become infected while they are in contact with the health care system. Health care associated infections also include occupational infectious diseases acquired by health care workers.

Health care associated infections are determined by a number of risk factors related to the patients themselves, the procedures they are exposed to, the organisms that cause disease, and buildings and rooms where treatment takes place (Fig. 1). Patients have an increased susceptibility to infection because they are weakened by disease, and in addition often elderly. Old age weakens the immune system and the function of vital organs. Lifestyle factors such as poor quality food, lack of exercise, and tobacco and alcohol abuse also play a role. Invasive procedures, like surgery and insertion of catheters break down the natural barriers of skin and mucous membranes and thereby predispose for health care associated infections. Cytostatics and other immunosuppressive agents also enhance the risk of infection, and the same applies to broad spectrum antibiotics through their impact on the patients' endogenous microbial flora. Hospital bacteria may have an enhanced potential for producing health care associated infections. A high consumption of broad spectrum antibiotics selects for multi-drug resistant organisms, which spread in hospitals despite infection control measures. Their spread may be favoured by genetic links between antibiotic resistance and virulence factors such as adhesion to cell surfaces (Di Martino et al 1997) and medical devices. Building facilities also play a role. Overcrowding and lack of facilities for isolation of contagious patients predispose for health care associated infections. Reduction of domestic cleaning leads to accumulation of pathogens on contact surfaces, which may subsequently be transmitted to patients. 


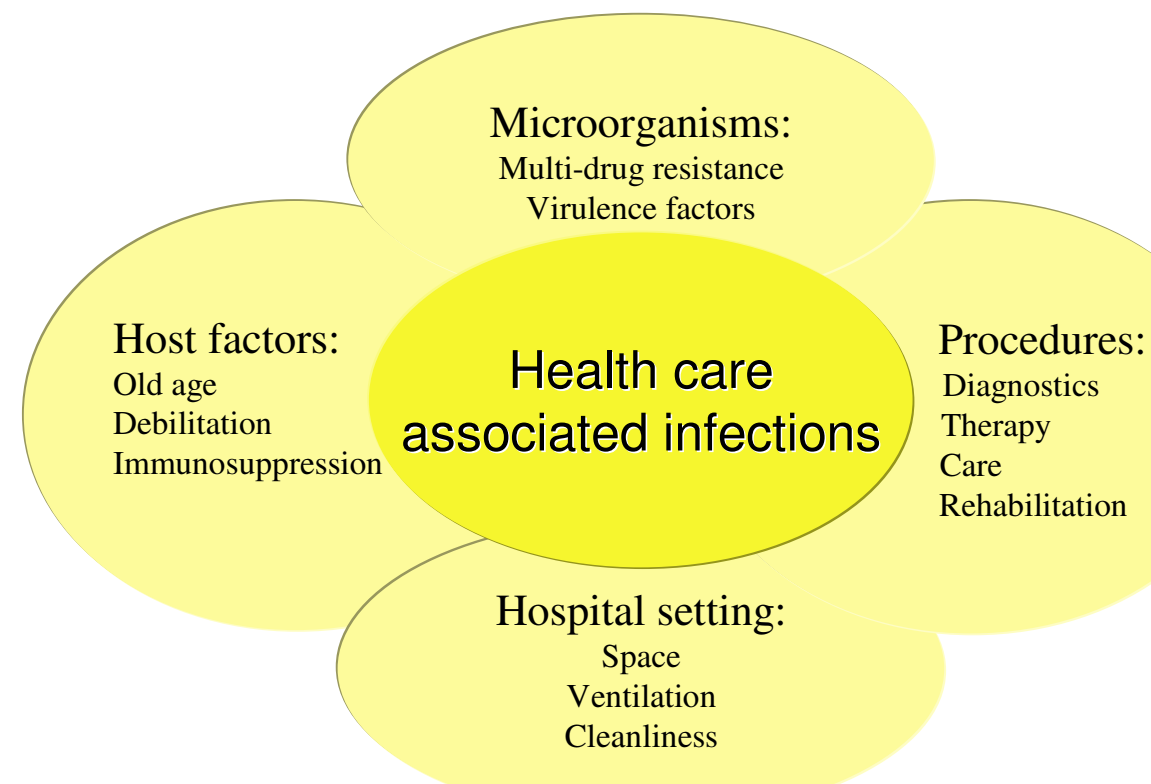

Fig. 1. Factors determining health care associated infections.

This aim of this paper is to give a comprehensive survey of the more important sources of health care associated infections and the way they are spread in the health care setting. The source of infection may be the patient's own microbial flora (self-infection), or organisms from other patients, hospital staff, and the hospital environment (cross-infection). Transmission may take place by direct or indirect contact, by the airborne route, or through a vehicle (e.g. water, food and drugs). Airborne transmission may take place by large particle droplets, by small particle droplets (droplet nuclei), and by dust. Table 1 summarizes the sources and modes of transmission, clarified by examples of risk factors and the types of infections they give rise to. A more detailed description of the single elements is given in the paragraphs below.

\section{Self-infection}

Patients may acquire health care associated infections from organisms belonging to their own normal flora on skin and mucous membranes. This colonizing flora may become invasive after break-down of natural barriers following surgery and insertion of catheters. The most important organisms are Staphylococcus aureus and Escherichia coli. Treatment with broad spectrum antibiotics may destroy the susceptible part of the endogenous flora, and instead patients become colonized with more resistant species originating from other patients or from the hospital environment. Examples of such resistant organisms are methicillin-resistant coagulase-negative staphylococci, ampicillin-resistant enterococci, Klebsiella pneumoniae, Pseudomonas aeruginosa and Stenotrophomonas maltophilia. This new colonizing flora may eventually give rise to infection. 


\begin{tabular}{|c|c|c|c|}
\hline $\begin{array}{l}\text { Sources of } \\
\text { infection }\end{array}$ & Modes of transmission & Examples of risk factors & Examples of infections \\
\hline Self-infection & $\begin{array}{l}\text { Break of natural barriers } \\
\text { (skin and mucous } \\
\text { membranes) }\end{array}$ & $\begin{array}{l}\text { Surgery. } \\
\text { Insertion of peripheral or } \\
\text { central line catheters. } \\
\text { Staphylococcus aureus carriage }\end{array}$ & $\begin{array}{l}\text { Surgical site infections } \\
\text { \& catheter related } \\
\text { infections due to } \\
\text { Staphylococcus aureus. } \\
\text { Urinary tract } \\
\text { infections due to } \\
\text { Escherichia coli }\end{array}$ \\
\hline \multirow{4}{*}{$\begin{array}{l}\text { Cross-infection } \\
\text { from other } \\
\text { patients }\end{array}$} & Via hands of staff & $\begin{array}{l}\text { Failing hand hygiene before } \\
\text { and after patient contact }\end{array}$ & $\begin{array}{l}\text { Surgical site infections } \\
\text { \& catheter related } \\
\text { infections due to } \\
\text { Staphylococcus aureus } \\
\text { Respiratory tract } \\
\text { infections due to RSV } \\
\text { \& other respiratory } \\
\text { pathogens }\end{array}$ \\
\hline & $\begin{array}{l}\text { Via instruments \& } \\
\text { equipment not properly } \\
\text { sterilized }\end{array}$ & $\begin{array}{l}\text { Heat-sensitive equipment, } \\
\text { e.g. fibre-optic endoscopes }\end{array}$ & $\begin{array}{l}\text { Tuberculosis } \\
\text { transmitted by fibre- } \\
\text { optic bronchoscope }\end{array}$ \\
\hline & Via the environment & $\begin{array}{l}\text { Insufficient domestic } \\
\text { cleaning leading to } \\
\text { accumulation of pathogens } \\
\text { on contact surfaces }\end{array}$ & $\begin{array}{l}\text { Diarrhoea due to } \\
\text { Clostridium difficile }\end{array}$ \\
\hline & Via donor blood \& drugs & $\begin{array}{l}\text { Medication of several } \\
\text { patients From the same } \\
\text { multi-dose vial }\end{array}$ & $\begin{array}{l}\text { Hepatitis B or C } \\
\text { transmitted with } \\
\text { drugs from multi-dose } \\
\text { vials accidentally } \\
\text { contaminated with } \\
\text { blood or body fluids } \\
\end{array}$ \\
\hline \multirow{2}{*}{ Hospital staff } & Hand-borne & $\begin{array}{l}\text { MRSA carriage. } \\
\text { Insufficient handhygiene in } \\
\text { connection with treatment } \\
\text { and care of patients }\end{array}$ & $\begin{array}{l}\text { Surgical wound } \\
\text { infections. } \\
\text { Catheter related } \\
\text { infections }\end{array}$ \\
\hline & Air-borne during surgery & $\begin{array}{l}\text { Carrrier of Streptococcus } \\
\text { pyogenes in the operating } \\
\text { theatre }\end{array}$ & $\begin{array}{l}\text { Puerperal fever \& } \\
\text { surgical wound } \\
\text { infections with } \\
\text { Streptococcus pyogenes }\end{array}$ \\
\hline \multirow[t]{2}{*}{$\begin{array}{l}\text { Hospital } \\
\text { environment }\end{array}$} & $\begin{array}{l}\text { Contact with } \\
\text { contaminated tap water }\end{array}$ & \begin{tabular}{|l|} 
Aspiration of oral secretions \\
following ingestion of tap \\
water contaminated with \\
Legionella. \\
Immunosuppression \\
\end{tabular} & Legionella pneumonia \\
\hline & $\begin{array}{l}\text { Inhalation of dust from } \\
\text { buildings }\end{array}$ & $\begin{array}{l}\text { Rebuilding of hospitals. } \\
\text { Immunosuppression }\end{array}$ & $\begin{array}{l}\text { Lung infection due to } \\
\text { Aspergillus fumigatus }\end{array}$ \\
\hline
\end{tabular}

Table 1. Sources of healthcare associated infections, modes of transmission, and associated risk factors illustrated by examples 


\subsection{Staphylococcus aureus carriage}

About $25 \%$ of the normal population are chronic carriers of Staphylococcus aureus, and the carriage rate is even higher - around $50 \%$ - in insulin dependent diabetics, dialysis patients, and intravenous drug addicts (Kluytmans et al 1997). The primary carriage sites are nostrils and throat, from where the organism is spread to the skin. Persons with a high concentration of Staphylococcus aureus in their nostrils have a three to six times higher risk of acquiring surgical wound infections, as compared to non carriers or persons with only a low concentration (Bode et al 2010). The same applies to catheter related infections in dialysis patients and patients with long term indwelling intravenous catheters. The pathogenesis is only partly understood, but it probably plays a role that most nasal carriers are at the same time skin carriers. Prospective studies have shown that more than $80 \%$ of all Staphylococcus aureus blood stream infections are of endogenous origin (von Eiff et al 2001). As to surgical site infections the origin of Staphylococcus aureus is less well described; however, it is estimated that at least $50 \%$ are due to self-infection (Perl et al 2002). The evidence for a causative relationship between Staphylococcus aureus carriage and risk of surgical wound infection is proved by the fact that preoperative eradication of Staphylococcus aureus carriage leads to a substantial reduction in surgical site infections (Bode et al 2010).

\subsection{Gram-negative bacilli}

Escherichia coli and other intestinal organisms may give rise to ascending urinary tract infections in patients with indwelling urinary catheters (Tambyah et al 1999) and to wound infections following abdominal surgery. Enterobacteria may also colonize the airways of critically ill patients and give rise to ventilator associated pneumonia. In healthy individuals the throat flora is dominated by Gram-positive bacteria, which adhere to cell surfaces by surface molecules such as fibronectin. However, in critically ill patients throat epithelial cells often lose their fibronectin-binding surface molecules and thereby their capacity to bind Gram-positive bacteria. This paves the road for colonization with enterobacteria and other Gram-negative bacilli (Woods 1987).

Ventilator associated pneumonia is often due to silent aspiration of bacteria-bearing secretions from the upper airways, which leak down along the outer side of the endotracheal tube. The aspirated material may also originate from the stomach, which has been colonized with intestinal flora following prophylactic treatment with antacids (Safdar et al 2005). The role of aspiration in ventilator associated pneumonia is the major rationale for using selective decontamination of the oropharynx and digestive tract to prevent such cases (Van Saene et al 2003)

\section{Cross infection}

The most important route of transmission of organisms from patient to patient is by indirect contact via staff's hands because hand hygiene is neglected or performed inadequately (Fig. 2). Transmission may also occur by direct contact between patients or by the airborne route, if they are placed on the same ward.

Staff is not the only factor involved in cross transmission. It may also occur via the environment by contact with surfaces that have been contaminated with organisms from other patients (fomites). This will be discussed in a separate paragraph below. Finally, cross 
transmission may occur via equipment and utensils that have not been decontaminated adequately before being reused, and through drugs and blood products. These aspects will also be covered in separate paragraphs below.
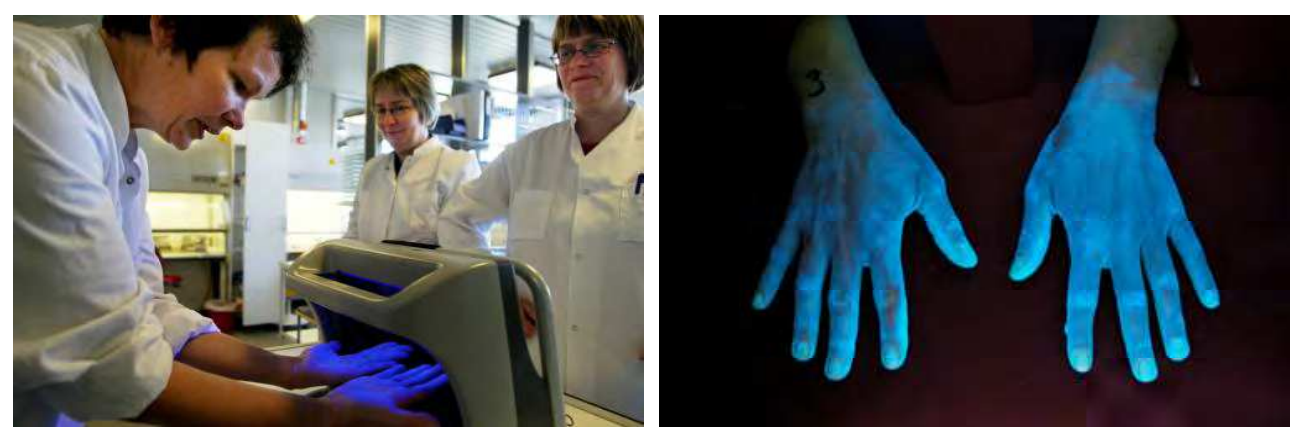

Fig. 2. The quality of hand hygiene may be visualised with fluorescent alcohol in an ultraviolet light box. Studies have shown that even experienced staff may have a low technical performance (Kolmos et al 2006). Right-hand persons often miss the back of their right hand and fingers, as illustrated on the photo to the right (courtesy: Infection Control Team, Odense University Hospital).

\subsection{Cross transmission by health care workers' hands}

The importance of cross transmission by health care workers' hands has been documented in a large number of studies (Pittet et al 2006). Wearing rings increases the level of skin contamination by a factor ten (Trick et al 2003). Artificial nails are also associated with increased levels of pathogens on hands (McNeil et al 2001). Pathogens are transmitted to health care workers' hands during contact with patients and their body secretions, and during contact with touch sites in the environment that have been contaminated with pathogens released from patients (Fig. 3). Hands become progressively contaminated during patient care: the longer the duration of care, the higher the level of contamination. Skin contact, diaper change, and respiratory care are associated with particularly high levels of transmission (Pessoa-Silva et al 2004). Most pathogens from patients can survive for sufficient time on health care workers' hands to be transmitted to other patients in a busy hospital setting. Organisms tolerant to desiccation form a particular problem. Examples of such agents are Staphylococcus aureus and other staphylococci, enterococci, Clostridium difficile, Acinetobacter baumannii and naked viruses such as noro- and rotavirus. However, organisms adapted to moist environments are also readily transmissible. Examples of such agents are Escherichia coli, Klebsiella pneumoniae, Pseudomonas aeruginosa, and more fragile viruses such as influenza virus and respiratory syncytial virus (RSV). Gloves offer some protection, but do not fully protect health care workers' hands from contamination. Model calculations indicate that they only halve skin contamination in connection with heavily contaminated procedures such as respiratory care and diaper change (Pessoa-Silva et al 2004).

The role of health care workers' hands in cross transmission of organisms is best illustrated by the ability of hand hygiene campaigns to reduce health care associated infections. A striking example is the study by Pittet and coworkers, where a hospital-wide hygiene campaign with emphasis on alcoholic hand rub led to a sustained increase in hand hygiene 
compliance and a reduction in hospital acquired infections by more than $40 \%$. Transmission of MRSA was reduced by more than 50 \% (Pittet et al 2000).

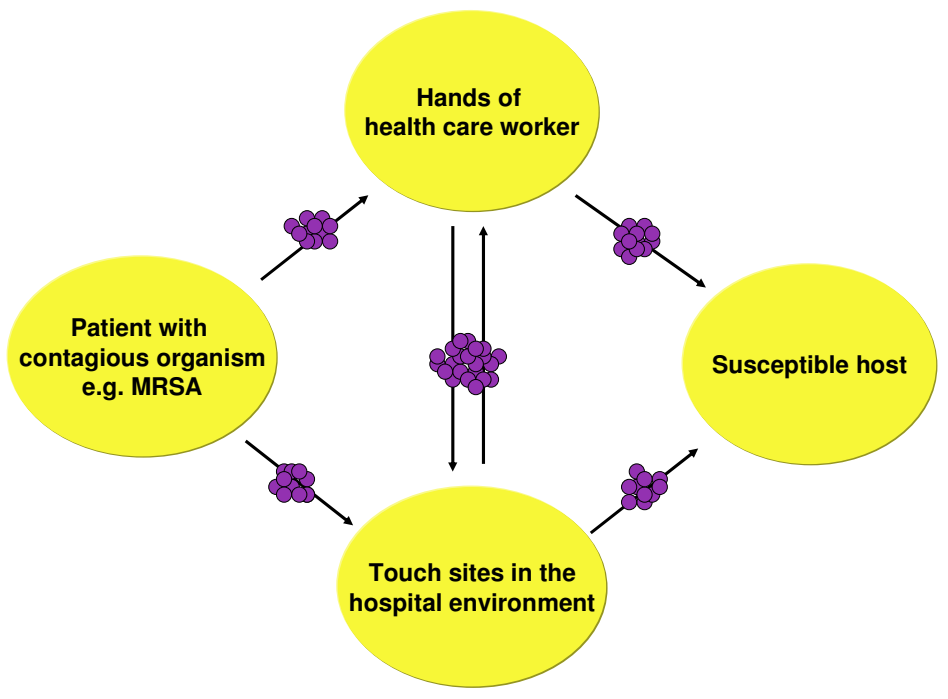

Fig. 3. Interactions between health care workers' hands and touch sites in the hospital environment on transmission of pathogens from one patient to another.

\subsection{The role of airborne transmission}

Many respiratory pathogens are transmitted from patient to patient by the airborne route. The large majority are carried by large droplets. This applies particularly to RSV, influenza and common cold viruses, and to bacteria like pneumococci, meningococci and haemolytic streptococci. Large droplets settle rapidly, and these organisms are therefore only directly transmissible within a distance of 1 or 2 metres from the infected patient. However, more importantly these organisms can also be transmitted by indirect contact, particularly with staff's hands, if hand hygiene is neglected between patient contacts. Transmission may also take place after contact with contaminated surfaces close to an infected patient (fomites). This has been clearly documented with RSV (Hall 2000), but probably also applies to the other respiratory pathogens mentioned above. Measles, rubella and varicella-zoster virus are mainly spread by droplet nuclei, which can keep airborne for long time and therefore be transmitted over long distances (Tang et al 2006, Roy \& Milton 2004).

Laboratory studies indicate that Mycobacterium tuberculosis can be transmitted by droplet nuclei; however the clinical significance of this remains controversial (Fennelly et al 2004, Nardell 2004). Transmission by large droplets plays a much larger role. Furthermore, Mycobacterium tuberculosis can survive for long time in dust and dried up secretions, which implies that it also has a potential for transmission by fomites.

The mode of transmission of influenza virus is still controversial. Most clinical studies point to transmission by contact and airborne transmission by large droplets; however, airborne 
transmission by droplet nuclei also seems to play a role. This is particularly the case with influenza pneumonitis, which is associated with the generation of droplet nuclei (Brankston et al 2007, Tellier 2006). Tracheal suctions and endotracheal intubation give rise the formation of aerosols, which may pose a risk to health care workers involved with these procedures.

\section{Health care workers as a source of health care associated infections}

As illustrated above health care workers play a key role in transmitting organisms from one patient to another. However, they may also be a source of infection themselves, if they are colonized or infected with pathogens which they pass on to patients. This applies particularly to Staphylococcus aureus, including MRSA, haemolytic streptococci (Streptococcus pyogenes), and to influenza A and hepatitis B viruses.

\subsection{Staphylococcus aureus}

At least $25 \%$ of all staff are permanent carriers of Staphylococcus aureus in their nostrils. From here the organism is spread to skin and hands. Special attention has been paid to carriers of MRSA, however, ordinary susceptible staphylococci are equally transmissible. As a rule the risk of transmitting Staphylococcus aureus from asymptomatic nasal carriers is low, provided that they perform proper hand hygiene before contact with patients. However, the risk may rise dramatically with sneezing, if they catch a common cold or suffer from a burst of hay fever. Rhinorrhoea and sneezing transforms a staphylococcal carrier into a staphylococcal disperser (Sherertz et al 2001, Bassetti et al 2005, Bischoff et al 2006). It is often referred to as the cloud phenomenon, indicating that the carrier is virtually surrounded by a cloud of staphylococci, when sneezing. Bacteria expelled by sneezing are usually carried on large droplets that will settle within a distance of 1-2 metres. Thus staphylococci from a carrier will not spread airborne over long distances; however, the organisms may settle on surfaces and act as fomites, which can be transmitted to patients by contact, if surfaces are not properly cleaned (Kramer et al 2006). Staphylococcal carriers with scaling skin diseases may also shed large amounts of organisms to the environment.

\subsection{Streptococcus pyogenes}

Haemolytic streptococci (Streptococcus pyogenes) can be contagious with an extremely low inoculum. Surgical staff and staff attending wounds may be a source of severe surgical wound infections and puerperal fever, if they are carriers of Streptococcus pyogenes . Several outbreaks have been reported that could be traced to a carrier (Kolmos et al 1997). Approximately $5 \%$ of the normal population are healthy throat carriers. This may involve a risk of transmission, particularly in relation to a common cold (cloud phenomenon, see above). However, more remarkably vaginal and anal carriage also seems to involve a high risk during surgery. Anal carriage may be seen in relation to minor disorders such as haemorrhoids and fissures; vaginal carriage is probably secondary to anal carriage. The mode of transmission from anal and vaginal carriers during surgery is not fully understood; however, the fact that carriers have given rise to outbreaks even without being close to patients in the operating theatre suggests that airborne transmission plays a role. Two cases of surgical wound sepsis due to Streptococcus pyogenes arising close to each other shortly after surgery is an alarm signal that should lead to considerations about a carrier among the surgical staff. 


\subsection{Influenza and other respiratory tract infections}

Health care workers are considered the main source of nosocomial influenza (Salgado et al 2002). The primary reason is that they meet on work with symptoms that are interpreted as a common cold, but are in fact influenza. Half of all cases of influenza A virus infection do not give rise to classical flu symptoms, but are subclinical or present with ordinary cold symptoms. The role of staff in the transmission of nosocomial influenza was highlighted in a Scottish study where vaccination of the staff led to a substantial decrease in mortality among residents in long-term care facilities over a winter season (Carman et al 2000). Staff in pediatric units may also transmit Bordetella pertussis (whooping cough) and RSV, which frequently give rise to re-infections with uncharacteristic cold symptoms in adulthood (Sherertz et al 2001, Singh \& Lingappan 2006, Hall et al 2001).

\subsection{Blood borne viruses}

Transmission of hepatitis B virus (HBV) to patients by infected surgeons has been reported in several studies. Transmission presumably takes place during surgery where the operating field is exposed to blood from the surgeon in connection with needle sticks and other skin injuries. Clusters of cases have primarily been seen with surgeons, whose serum contained hepatitis B e antigen (HBeAg), which is associated with particularly high concentrations of circulating virus and therefore great infectivity; however, $\mathrm{HBeAg}$ negative surgeons have also infected patients (The Incident Investigation Teams and Others 1997). Surgeons may also transmit hepatitis C virus and HIV (Heptonstall 2000).

\section{Cross transmission by medical devices}

Instruments and utensils may transmit pathogens if they are not decontaminated properly after patient use. The transmitted pathogens may originate from other patients, or from sources in the hospital environment. Overall, these problems have been declining over the past decades due to the introduction of more single-use equipment and safer and more efficient disinfecting techniques for multiple-use equipment. One of the more important improvements is the introduction of ward based automatic washing machines with heat disinfection programmes, which have replaced older and less safe techniques based on the use of chemical disinfectants. However, in recent years new challenges have arisen with the introduction of fragile and sophisticated equipment, which cannot be heat sterilized.

\subsection{Fibre-optic endoscopes}

Fibre-optic endoscopes are an example of such heat sensitive equipment. Decontamination takes place by a combination of mechanical cleansing with an enzymatic cleaner and chemical disinfection with a high level disinfectant, such as peracetic acid or glutaraldehyde (Rutala \& Weber 2004). The process may be performed manually, but usually takes place in an automatic disinfector (Fig. 4). Bronchoscopes are the medical devices that most commonly give rise to hygienic problems. Numerous outbreaks and pseudo-outbreaks due to the use of contaminated bronchoscopes have been reported, both with person-to-person transmission of pathogens (e.g. Mycobacterium tuberculosis), and transmission of pathogens from the environment (e.g. Mycobacterium chelonae and Pseudomonas aeruginosa). Contamination has been associated with breaches in technique both in the bronchoscopes 
and the disinfecting machines used for reprocessing (Weber \& Rutala 2001, Srinivasan et al 2003). By contrast, transmission of infection has only been recognized in very few cases with endoscopes used in gastrointestinal endoscopy (Nelson \& Muscarella 2006).

The sterility safety of surgical instruments is extremely high, given that they are reprocessed and sterilized under well controlled conditions in an autoclave. However, one matter of concern is the emergence new prion-related disorders, like variant Creutzfeldt-Jakob disease (CJD), since this type of prion protein is not fully inactivated by traditional autoclaving. Instruments that have been in contact with brain, spinal cord, eye tissues, lymph nodes, spleen, and terminal ileum pose a special risk for transmitting variant CJD (Sutton et al 2006).

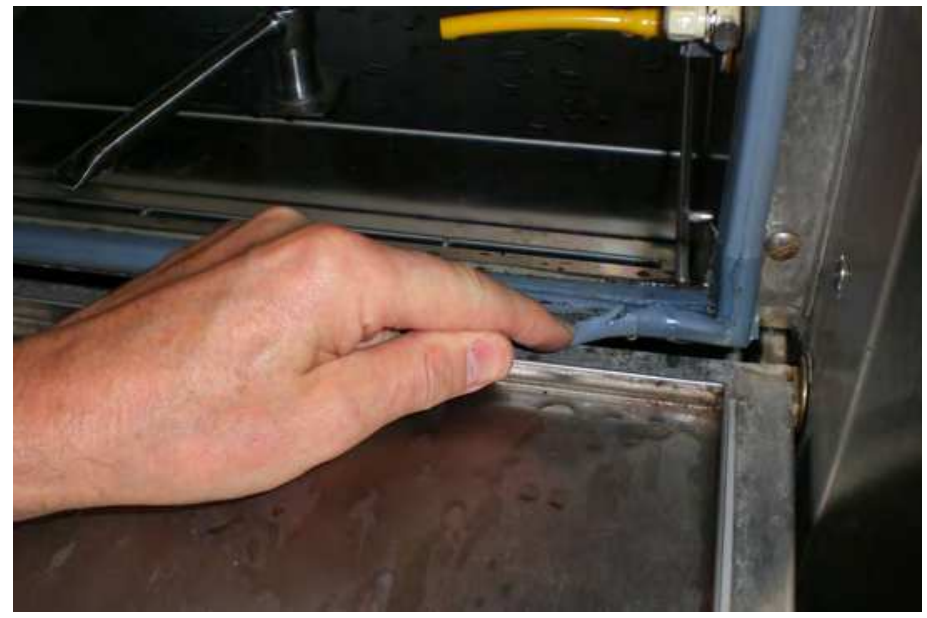

Fig. 4. Damaged rubber gasket in a poorly maintained disinfector used for reprocessing endoscopes. Formation of biofilm in the disinfector resulted in a pseudo-outbreak of Mycobacterium gordonae among patients undergoing bronchoscopy with bronchoscopes reprocessed in the disinfector (Courtesy: Infection Control Team, Odense University Hospital).

\section{Infections transmitted through a vehicle}

Transmission of organisms from other patients or from the environment may take place through a vehicle, e.g. water, food, drugs, and donor blood.

\subsection{Tap water}

Tap water in most hospitals is colonized with Legionella pneumophila, which may give rise to pneumonia and other severe manifestations in immunocompromised patients, such as organ transplant recipients. Patients with impaired throat reflexes and intubated patients are other important risk groups. The most important mode of transmission is by silent aspiration of contaminated secretions from the oral cavity (Sabria \& Yu 2002). Contamination of the oral cavity may occur with drinks or ice cubes made from tap water, or with tap water used for oral hygiene. Thus, transmission of Legionella in hospitals differs significantly from transmission outside the health care setting, where transmission usually takes place through inhalation of aerosols from contaminated air condition facilities. It is 
often assumed that showering plays a role in transmission of Legionella in hospitals, but there is little evidence that this is actually the case (Sabria \& Yu 2002).

Contaminated tap water may give rise to wound infections, if used for cleansing wounds. This was for instance the case in an outbreak of Pseudomonas aeruginosa infections in a burns unit, where tap water was used for irrigation of burns as part of the first aid treatment, which patients received when entering the hospital. Contamination was restricted to the showers and plastic tubing, which were permanently connected to the taps. This led to stagnant water inside the tubings and heavy contamination due to biofilm formation. Water sampled directly from the taps of the metal pipes was not contaminated, and the outbreak stopped, when plastic tubings and showers were dismantled and disinfected (Kolmos et al 1993).

\subsection{Food}

Virtually any food pathogen that occurs in the community can give rise to food borne infections in the health care setting. Much attention is being paid to zoonotic Salmonella enterica, which despite enhanced surveillance strategies still gives rise hospital outbreaks (Sion et al 2000, Guallar et al 2004). Outbreaks due to Listeria monocytogenes have also been reported (Johnsen et al 2010). A characteristic feature of food borne outbreaks due to these organisms is that they predominantly hit debilitated patients, who have a much higher attack rate than other patients. A major reason for this is that they develop infection with a lower inoculum than other exposed patients, who often stay asymptomatic and therefore go unnoticed. Debilitated patients may therefore be regarded as a sentinel population for recognition of food borne outbreaks, with symptomatic cases representing only the tip of the iceberg.

Norovirus is another important pathogen, which may give rise to food borne outbreaks in the health care setting, affecting both patients and staff. The virus is extremely contagious, which implies that secondary cases often occur (Stevenson et al 1994). A food borne outbreak is therefore often a mix of food transmitted cases and secondary cases acquired by patient to patient transmission, which makes source identification more difficult.

Buffets carry a risk of cross transmission, particularly if food is handled by self-service (Fone et al 1999). The same applies to ice produced by ward based ice machines (Ravn et al 1991).

\subsection{Intravenous drugs}

Despite efforts to improve safety, transmission of blood borne viruses through intravenous drugs is an ongoing problem.

In recent years there have been reports on transmission of both hepatitis B and C viruses, as well as HIV (Fisker et al 2006, Wenzel \& Edmond 2005, Katzenstein et al 1999). In the majority of cases the sources of infection were capped multi-dose vials used for medication of a series of patients. Virus may be spread to the vials by accidental reuse of hypodermic needles and syringes contaminated with virus after medication of infected patients. Alternatively, the rubber membrane of vials may become contaminated with blood aerosols if blood specimens are handled close by, and virus may be introduced by subsequent needle perforations, if the membrane is not disinfected properly. This was probably the case in a recent outbreak of hepatitis B virus infection in a paediatric oncology ward (Fig. 5). Due to crowding and lack of proper room facilities the ward's preparation room was used for collecting blood samples, drying bone marrow smears and occasionally for blood sampling 
and transfusions, and multi-dose vials in use were placed next to the disposal pot for used hypodermic needles and syringes (Fisker et al 2006). Similarly, a large outbreak of hepatitis $C$ virus infection among haematology/oncology patients visiting an outpatient clinic could be traced back to shared saline bags. Contamination of the saline bags probably occurred because the syringe used for collection of blood specimens from the patient was reused to withdraw saline to flush the catheter after blood sampling (Macedo de Oliveira et al 2005).

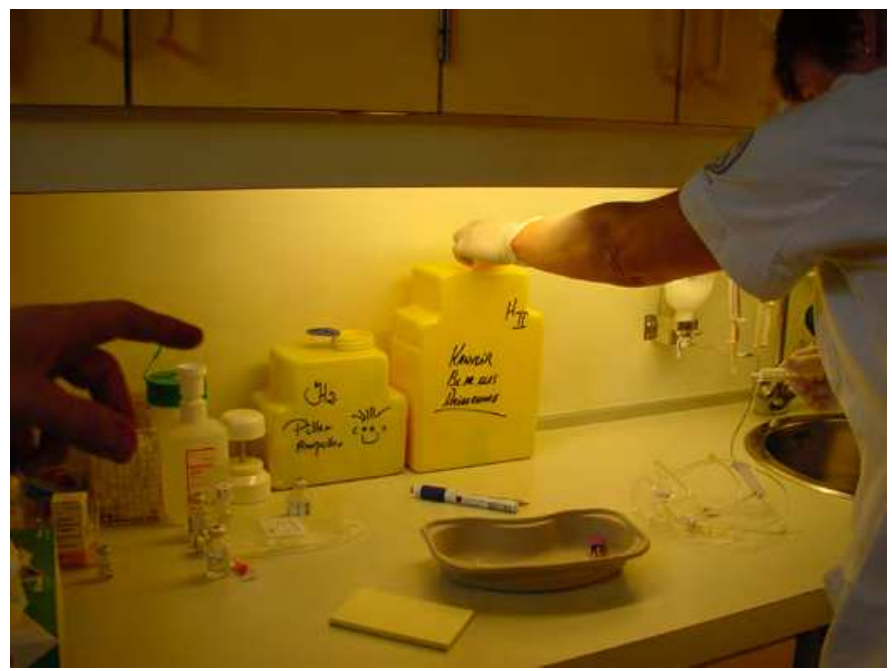

Fig. 5. Snapshot showing the preparation of an infusion with cytostatic agents in the preparation room of a paediatric oncology unit. To the right is the infusion line, rolled up on the table and connected to the infusion bag (hidden behind the nurse). To the left are several multi-dose vials with broken seals, containing drugs for preparation of the infusion. Between the infusion line and multi-dose vials is a bowl with a blood sample from a patient and disposal pots for hypodermic needles, syringes, and vials. This mingling of sterile procedures with handling of blood specimens and disposal of used needles gave rise to a large outbreak of hepatitis B (Fisker et al 2006) (Courtesy: Infection Control Team, Odense University Hospital).

\subsection{Donor blood and blood products}

Transfusion blood is not a sterile product. Donors may be silent carriers of blood borne viruses, like HBV, HCV, HIV, and HTLV, which may be transmitted to recipients of blood and blood products. Transmission of bacteria like Yersinia enterocolitica and protozoa like Plasmodium falciparum from apparently healthy donors has also been reported (Leclercq et al 2005, Bihl et al 2007). Rigorous screening of donors and pathogen inactivation in blood components have minimized such cases; however, donor blood may still be contaminated as a result of management errors in the blood bank during collection, preparation, and storage of blood and blood products. Transfusion related bacteraemia may also arise from contaminated blood collection bags. This was the case in a nationwide outbreak of Serratia marcescens bacteraemia among transfusion recipients, which could be traced back to commercial blood collection bags contaminated at the production plant. Water used for cooling the bags upon autoclaving was the source of contamination (Heltberg et al 1993). 


\section{Hospital environment}

\subsection{Cross infection from contaminated surfaces (fomites)}

Cross infection may take place by contact with contaminated surfaces (fomites) in the health care setting. Examples of contact surfaces are door handles, bed tables, chairs, toilet seats, and floors.

Patients discharge large amounts of organisms to the hospital environment, particularly if they suffer from skin, wound, and respiratory tract infections, and from diarrhoea (Fig. 6). The discharged organisms settle with skin scales, droplets, and secretions on contact surfaces and accumulate in dust. From here they may be passed on to other patients, if they touch the contaminated surfaces. Health care workers also play a role in transmission if they touch contaminated surfaces and neglect hand hygiene before patient contact.

Organisms that are tolerant to dessication have a particularly high potential for transmission in the health care setting, because they keep viable for long time in the environment after having been discharged from patients. Such organisms are Clostridium difficile, Staphylococcus aureus, Acinetobacter baumannii, Enterococcus faecium, and Mycobacterium tuberculosis. Yeasts, and naked viruses like norovirus can also survive for long time outside the human body. Until recently microbial contamination of the hospital environment was considered unimportant in regard to transmission of health care associated infections. However, this has changed with the emergence of new evidence indicating that cross transmission from the environment is in fact a common phenomenon that has to be taken into consideration (Dancer 2008, Dancer 2011).

One way to illustrate a relationship between contamination of the hospital environment and health care associated infections is to study the risk of acquiring a specific pathogen, if a patient is admitted into a room that was previously occupied by a patient colonized or infected with the same pathogen. With this setup an increased risk of acquisition has been shown with Clostridium difficile, methicillin resistant Staphylococcus aureus (MRSA), vancomycin resistant Enterococcus (VRE), and Acinetobacter baumannii (Carling \& Bartley 2010). The excess risk of acquiring MRSA and VRE was studied in a large multi-centre cohort study comprising more than 10,000 ICU patients, who underwent routine admission and weekly screenings for these two agents. The risk increased by $40 \%$, if patients were admitted into rooms previously occupied by patients harbouring MRSA or VRE (Huang et al 2006). A subsequent intervention study with focus on adherence to defined cleaning standards, including the use of a quaternary ammonium agent, reduced contamination with both organisms, and more importantly, it eliminated the excess risk of acquiring MRSA, whereas the risk of acquiring VRE remained largely unchanged (Datta et al 2011). This study confirms a previous report, where an outbreak of MRSA in a urological ward was contained successfully after intensifying domestic cleaning with special focus on dust removal and use of alcohol to disinfect contact surfaces (Rampling et al 2001). Similarly, the frequency of Clostridium difficile associated diarrhoea was reduced significantly in a number of wards, after the organism had been eliminated from the environment by hydrogen peroxide vapour (Boyce et al 2008).

\subsection{Dust from demolition and construction works}

Demolition and construction of buildings are ongoing processes in all big hospitals. Dust from building materials contains large amounts of spores of environmental fungi, which may pose a threat to heavily immunocompromised patients. (Hansen et al 2008). There are 
numerous reports of outbreaks of severe fungal respiratory tract infections among haematology, oncology and organ transplant patients originationg from inhalation of contaminated dust that could be traced back to demolition and renovation works in the hospital setting. The fungi most frequently involved were Aspergillus fumigatus and Aspergillus flavus (Vonberg \& Gastmeier 2006).

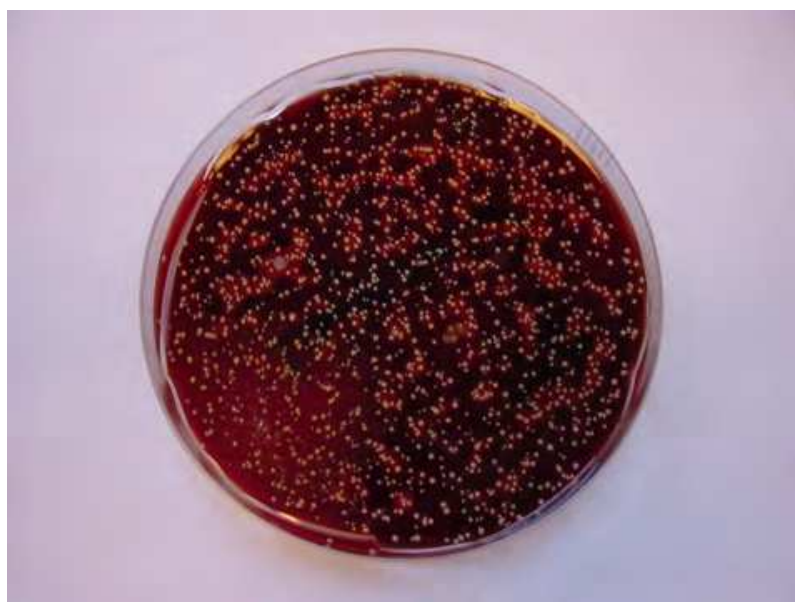

Fig. 6. Methicillin resistant Staphylococcus aureus (MRSA) on a sedimentation plate exposed for 12 hours on an overbed table of a dermatitis patient colonized with MRSA (Courtesy: Infection Control Team, Odense University Hospital).

\section{Discussion}

Sources and transmission routes of health care associated infections are numerous and complex. In many cases they are only partly understood, and the hygienic measures taken to control transmission are not always ideal. In many areas there is a need for more research to clarify the epidemiology and pathogenesis of health care associated infections in order to develop and implement more efficient and targeted interventions. This research should focus not only on technical and biological aspects, but should also involve behavioural sciences, since human behaviour is one of the key factors in transmission of infections in the health care setting.

Failure to perform hand hygiene is probably the single most important factor in transmission of health care associated infections. Taking into account the strength of evidence for the importance of hand hygiene, it is noteworthy that compliance is still so low. Several studies have documented that in daily clinical practice hand hygiene is hardly performed in more than half of the cases where it should, and only one third of those who perform hand hygiene do it correctly (Kolmos et al 2006). A major reason is probably that the complexity of hand hygiene is grossly underestimated. It is often taken for granted that everybody masters the technique; however, to clean hands requires in fact a systematic and elaborate washing technique, which has to be trained. Furthermore, the tools for hand hygiene are far from optimal. A nurse in an intensive care unit with seven patient contacts each hour will for instance have to spend nearly one hour a day 
washing hands with soap and water, if the recommended procedure is to be followed (Voss \& Widmer 1997). Apart from being time consuming, this may give rise to skin problems. Alcoholic hand rub is faster and more gentle to the skin, and even more importantly, much more efficient to kill pathogens. It can replace soap and water in most cases, provided that hands are not visibly dirty (Pittet et al 2000). However, there are important exceptions: spore-forming bacteria, like Clostridium difficile and naked viruses, like norovirus (Kampf et al 2005) are not very susceptible to alcohol, which implies that health care workers must stick to soap and water, when dealing with patients suffering from infections due to these pathogens. It appears from this that what at first glance looks simple is in fact a demanding clinical procedure, which requires background knowledge and has to be trained in the same systematic manner as e.g. the skills necessary for insertion of an i.v. line. Essentially, hand hygiene techniques have not changed very much over the past century. With today's knowledge about the lack of compliance and quality with hand hygiene performance and the ability of some organisms to resist alcohol, there is a clear need for development of more efficient hand hygiene techniques that are universally applicable, and at the same time fast and user-friendly.

For many years it has been a matter of discussion, whether transmission of pathogens from the hospital environment plays a significant role in acquisition and spread of health care associated infections. A major reason is lack of well designed studies to document this route of transmission, which may be attributed to the fact that cleaning until recently was not considered an issue worth investigating (Dancer 2008). From the 1970s and until recently cleaning was considered merely an aesthetic issue, and budgets were cut down by hospital management in order to meet the demands for resources in other parts of the health care system. This was endorsed even by infection control practitioners, partly because of the lack of evidence for its importance as an infection control measure, partly because they feared that focus on cleaning would draw attention away from more important measures, like hand hygiene. This attitude has gradually shifted with the emergence of new well designed studies highlighting the role of the environment in transmission of hospital acquired infections and the ability of disinfecting cleaning to reduce such cases (Boyce et al 2008, Dancer 2008, Datta et al 2011).

Accumulating evidence suggests that there is a dynamic interaction between the hands of health care workers and the environment in transmitting organisms from one patient to another (Dancer 2008) (Fig. 3). The question whether focus should be put on hand hygiene or cleaning the hospital environment is no longer meaningful. It is not an either or, rather it is a both and. If cross transmission is to be controlled there is a need to develop new and more efficient methods both for hand hygiene and environmental decontamination. Current cleaning methods used in the health care setting are primarily designed to fulfil aesthetic purposes, and they do not remove organisms from touch sites in the environment to any significant degree (French et al 2004). Cleaning combined with liquid disinfectants, such as hypochlorite and quaternary ammonium agents reduces surface contamination with pathogens, like Clostridium difficile, MRSA, and VRE (Wilcox et al 2003, Datta et al 2011). However, occupational hazards and concern for the environment implies that they are not used in daily routine cleaning. Hydrogen peroxide fumigation is an efficient and attractive alternative from an environmental point of view (French et al 2004, Boyce et al 2008). However, it is not suited for daily routine cleaning either. Clearly there is a need for more user-friendly 
methods that can be used in daily practice to decontaminate touch sites, without posing any risks to humans, materials, and environment. Furthermore, we are in need of universally accepted standards to define and monitor microbial cleanliness of surfaces (Dancer 2011).

Transmission of pathogens by heat sensitive equipment, such as bronchoscopes is still a matter of concern. Problems usually relate to breaches in technique, both in the bronchoscopes and the disinfectors used for reprocessing. Failures in maintenance are one of the major reasons for technical breaches that lead to failing disinfection and eventually to transmission of pathogens to patients undergoing examination (Fig. 4). An important reason for failures is that responsibilities for maintenance are often shared by different parties, and demands are not always clearly defined. Furthermore, when buying this type of equipment there may be a tendency to underestimate working expenses for maintenance, which usually requires paid expertise from an external supplier. In a situation with need for budget cuts, reduction of maintenance may be one way to obtain savings, which may become critical if responsibilities and demands are not clearly defined. A clear definition of responsibilities and documentation of maintenance in accordance with written guidelines are essential measures to secure a satisfactory hygienic standard with this type of fragile equipment. Furthermore, when negotiating with a supplier, purchase and maintenance of equipment should be seen as one combined package, defining a plan for its maintenance in the years ahead. Finally, producers of fibre-optic endoscopes should be encouraged to produce more robust equipment, which can tolerate safer sterilization methods, if possible based on heat.

This review has focused on the sources and routes of transmission seen today and over the past few decades. However, it is important to note that the situation is not static. Growing age and debilitation of patients predispose for more infections. Furthermore, since health care associated infections are in part determined by the procedures used in diagnostics, treatment, care and rehabilitation they change with the development of the health care system. New sources and transmission routes emerge, while others disappear. The risk of new infections can be minimized by making a systematic hygienic risk assessment, when introducing new health care procedures and new technology, and by keeping a sharp eye on unsuspected findings in the microbiology laboratories (Kolmos 2001).

\section{References}

Bassetti, S.; Bischoff, WE.; Walter, M. et al. (2005). Dispersal of Staphylococcus aureus into the air associated with a rhinovirus infection. Infect Control Hosp Epidemiol; 26: 196-203.

Bihl, F.; Castelli, D.; Marincola, F. et al. (2007). Transfusion-transmitted infections. J Transl Med; 5: 25

Bischoff, WE.; Wallis, ML.; Tucker, BK. et al. (2006). “Gesundheit!” Sneezing, common colds, allergies and Staphylococcus aureus dispersion. J Infect Dis; 194: 1119-26.

Bode, L.; Kluytmans, J.; Wertheim, H. et al. (2010). Preventing surgical-site infections in nasal carriers of Staphylococcus aureus. N Engl J Med; 362: 9-17.

Boyce, JM.; Havill NL.; Otter, JA. et al. (2008). Impact of hydrogen peroxide vapor room decontamination on Clostridium difficile environmental contamination and transmission in the health care setting. Infect Control Hosp Epidemiol; 29: 723-9.

Brankston, G.; Gitterman, L.; Hirji, Z. et al. (2007). Transmission of influenza A in human beings. Lancet Infect Dis; 7: 257-65. 
Carling, PC. \& Bartley, JM. (2010). Evaluating hygienic cleaning in health care settings: What you do not know can harm your patient. Am J Infect Control; 38 (Suppl 1): S41-50.

Carman, WF.; Elder, AG.; Wallace, LA. et al. (2000). Effects of influenza vaccination of healthcare workers on mortality of elderly people in long-term care: a randomised controlled trial. Lancet; 355: 93-7.

Dancer, SJ. (2008). Importance of the environment in methcillin-resistant Staphylococcus aureus acquisition: the case for hospital cleaning. Lancet Infect Dis; 8: 101-13.

Dancer, SJ. (2011). Hospital cleaning in the 21 ${ }^{\text {st }}$ century. Eur J Clin Microbiol Infect Dis; 30: 1473-81.

Datta, R.; Platt, R.; Yokoe, DS. et al. (2011). Environmental cleaning intervention and risk of acquiring multi-drug resistant organisms from prior room occupants. Arch Intern Med; 171: 491-4.

Di Martino, P.; Sirot, D; Joly, B et al. (1997). Relationship between adhesion to intestinal caco-2 cells and multidrug resistance in Klebsiella pneumoniae clinical isolates. J Clin Microbiol; 35: 1499-1503.

Fennelly, KP.; Martyny, JW.; Fulton, KE. et al. (2004). Cough-generated aerosols of Mycobacterium tuberculosis. A new method to study infectiousness. Am J Respir Crit Care Med; 169: 604-9.

Fisker, N.; Carlsen, NL.; Kolmos, HJ. et al. (2006). Identifying a hepatitis B outbreak by molecular surveillance: a case study. BMJ; 332: 343-5.

Fone, DL.; Lane, W. \& Salmon, RL. (1999). Investigation of an outbreak of gastroenteritis at a hospital for patients with learning difficulties. Commun Dis Public Health; 2: 35-8.

French, GL.; Otter, JA.; Shannon, KP. et al. (2004). Tackling contamination of the hospital environment by methicillin-resistant Staphylococcus aureus (MRSA): a comparison between conventional terminal cleaning and hydrogen peroxide vapour decontamination. J Hosp Infect; 57: 31-7.

Guallar, C.; Ariza, J.; Dominguez, MA. et al. (2004). An insidious nosocomial outbreak due to Salmonella Enteritidis. Infect Control Hosp Epidemiol; 25: 10-5.

Hall, CB.; Long, CE. \& Schnabel, KC. (2001). Respiratory syncytial virus infections in previously healthy working adults. Clin Infect Dis; 33: 792-6.

Hall, CB. (2000). Nosocomial respiratory syncytial virus infections: the "Cold War"has not ended. Clin Infect Dis; 31: 590-6.

Hansen, D.; Blahout, B.; Benner, D. et al. (2008). Environmental sampling of particulate matter and fungal spores during demolition of a building on a hospital area. $J$ Hosp Infect; 70: 259-64.

Heltberg, O.; Skov, F.; Gerner-Smidt, P. et al. (1993). Nosocomial epidemic of Serratia marcescens septicemia ascribed to contaminated blood transfusion bags. Transfusion; 33: 221-7.

Heptonstall, J. (2000). Surgeons who test positive for hepatitis C should be transferred to low risk duties. Rev Med Virol; 10: 75-8.

Huang, SS.; Datta, R. \& Platt, R. (2006). Risk of acquiring antibiotic-resistant bacteria from prior room occupants. Arch Intern Med; 166: 1945-51.

Johnsen, BO.; Lingaas, E.; Torfoss, D. et al. (2010). A large outbreak of Listeria monocytogenes infection with short incubation period in a tertiary care hospital. J Infect; 61: 465-70.

Kallen, AJ.; Wilson, CT. \& Larson, RJ. (2005). Perioperative intranasal mupirocin for prevention of surgical-site infections: systematic review of the literature and metaanalysis. Infect Control Hosp Epidemiol; 26: 916-22.

Kampf, G.; Grotheer, D. \& Steinmann J. (2005). Efficacy of three ethanol-based hand rubs against feline calicivirus, a surrogate virus for Norovirus. J Hosp Infect; 60: 144-9. 
Katzenstein, T.; Jørgensen, LB.; Permin, H et al. (1999). Nosocomial HIV-transmission in an outpatient clinic detected by epidemiological and phylogenetic analyses. AIDS; 13: 1737-44.

Kluytmans, J.; van Belkum, A. \& Verbrugh, H. (1997). Nasal carriage of Staphylococcus aureus: Epidemiology, underlying mechanisms, and associated risks. Clin Microbiol Reviews; 10: 505-20.

Kolmos, HJ.; Thuesen, B.; Nielsen, SV. et al. (1993). Outbreak of infection in a burns unit due to Pseudomonas aeruginosa originating from contaminated tubing used for irrigation of patients. J Hosp Infect; 24: 11-21.

Kolmos, HJ.; Petersen, A.; Hilsberg, P. et al. (2006). Room for improvement: Two third of hospital staff do not use proper hand disinfection technique. J Hosp Infect; 64 (suppl 1): S54.

Kolmos, HJ.; Svendsen, RN. \& Nielsen SV. (1997). The surgical team as a source of postoperative wound infections caused by Streptococcus pyogenes. J Hosp Infect; 35: 207-14.

Kolmos, HJ. (2001). Role of the clinical microbiology laboratory in infection control - a Danish perspective. J Hosp Infect; 48 (Suppl A): S50-4.

Kramer, A.; Schwebke, I. \& Kampf, G. (2006). How long do nosocomial pathogens persist on inanimate surfaces? A systematic review. BMC Infect Dis; 6: 130.

Leclercq, A.; Martin, L.; Vergnes, ML. et al. (2005). Fatal Yersinia enterocolitica biotype 4 serovar O:3 sepsis after red blood cell transfusion. Transfusion; 45: 814-8.

Macedo de Oliveira, A.; White, KL; Leschinsky, DP. et al. 2005. An outbreak of hepatitis C virus infections among outpatients in a hematology/oncology clinic. Ann Intern Med; 142: 898-902.

McNeil, SA.; Foster, CL.; Hedderwick, SA. Et al. (2001). Effect of hand cleansing with antimicrobial soap or alcohol-based gel on microbial colonization of artificial fingernails worn by health care workers. Clin Infect Dis; 32: 367-72.

Nardell, EA. (2004). Catching droplet nuclei. Toward a better understanding of tuberculosis transmission. Am J Respir Crit Care Med; 169: 553-4.

Nelson, D. \& Muscarella, LF. (2006). Current issues in endoscope reprocessing and infection control during gastrointestinal endoscopy. World J Gastroenterol; 12: 3953-64.

Perl, TM.; Cullen, JJ.; Wenzel, RP. et al. (2002). Intranasal mupirocin to prevent postoperative Staphylococcus aureus infections. N Engl J Med; 346: 1871-7.

Pessoa-Silva, CL.; Dharan, S.; Hugonnet, S. et al. (2004). Dynamics of Bacterial Hand Contamination during Routine Neonatal Care. Infect Control Hosp Epidemiol; 25: 192-7.

Pittet, D.; Allegranzi, B.; Sax, H. et al. (2006). Evidence-based model for hand transmission during patient care and the role of improved practices. Lancet Infect Dis; 6: 641-52.

Pittet, D.; Hugonnet, S.; Harbarth, S. et al. (2000). Effectiveness of a hospital-wide programme to improve compliance with hand hygiene. Lancet; 356: 1307-12.

Rampling, A.; Wiseman, S.; Davis, L. et al. (2001). Evidence that hospital hygiene is important in the control of methicillin-resistant Staphylococcus aureus. J Hosp Infect; 49: 109-16.

Ravn, P.; Lundgren, JD.; Kjaeldgaard, P. et al. (1991). Nosocomial outbreak of cryptosporidiosis in AIDS patients. BMJ; 302: 277-80.

Roy, CJ. \& Milton, DK. (2004). Airborne transmission of communicable infection - the elusive pathway. N Engl J Med; 350: 1710-2.

Rutala, WA. \& Weber, DJ. (2004). Disinfection and sterilization in health care facilities: what clinicians need to know. Clin Infect Dis; 39: 702-9. 
Sabria, M. \& Yu, VL. (2002). Hospital-acquired legionellosis: solutions for a preventable infection. Lancet Infect Dis; 2: 368-73.

Safdar, N.; Crnich, CJ. \& Maki, DG. (2005). The pathogenesis of ventilator-associated pneumonia: Its relevance to developing effective strategies for prevention. Respir Care; 50: 725-39.

Salgado, CD.; Farr, BM.; Hall, KK. et al. (2002). Influenza in the acute hospital setting. Lancet Infect Dis; 2: 145-55.

Sherertz, RJ.; Bassetti, S.; Bassetti-Wyss, B. (2001). "Cloud" health-care workers. Emerg Infect Dis; 7: 241-4.

Singh, M.; Lingappan, K. (2006). Whooping cough. The current scene. Chest; 130: 1547-53.

Sion, C.; Garrino, M-G.; Glupczynski, Y. et al. (2000). Nosocomial outbreak of Salmonella enteritidis in a university hospital. Infect Control Hosp Epidemiol; 21: 182-3.

Srinivasan, A.; Wolfenden, LL.; Song, X. et al. (2003). An outbreak of Pseudomonas aeruginosa infections associated with flexible bronchoscopes. N Engl J Med; 348: 221-7.

Stevenson, P.; McCann, R.; Duthie, R. et al. (1994). A hospital outbreak due to Norwalk virus. J Hosp Infect; 26:261-72.

Sutton, JM.; Dickinson, J.; Walker, JT. et al. (2006). Methods to minimize the risk of CreutzfeldtJakob disease transmission by surgical procedures: where to set the standard? Clin Infect Dis; 43: 757-64.

Tambyah, PA.; Halvorson, KT. \& Maki DG. (1999). A prospective study of pathogenesis of catheter-associated urinary tract infection. Mayo Clin Proc; 74: 131-6.

Tang, JW.; Li ,Y.; Eames, I. et al. (2006). Factors involved in the aerosol transmission of infection and control of ventilation in health care premises. J Hosp Infect; 64: 100-14.

Tellier, R. (2006). Review of aerosol transmission of influenza A virus. Emerg Infect Dis; 12: 1657-62.

The Incident Investigation Teams and Others. (1997). Transmission of hepatitis B to patients from four infected surgeons without hepatitis B e antigen. N Engl J Med; 336: 178-84.

Trick, WE.; Vernon, MO.; Hayes, RA. et al. (2003). Impact of ring wearing on hand contamination and comparison of hand hygiene agents in a hospital. Clin Infect Dis; 36: 1383-90.

Van Saene, HKF.; Petros, AJ.; Ramsay, G. et al. (2003). All great truths are iconoclastic: selective decontamination of the digestive tract moves from heresy to level 1 truth. Intensive Care Med; 29: 677-90.

Von Eiff, C.; Becker, K.; Machka, K. et al. (2001). Nasal carriage as a source of Staphylococcus aureus bacteremia. N Engl J Med; 344: 11-6.

Vonberg, R-P.; Gastmeier, P. (2006). Nosocomial aspergillosis in outbreak settings. J Hosp Infect; 63: 246-54.

Voss, A. \& Widmer, AF. (1997). No time for hand washing!? Hand washing versus alcoholic rub: can we afford 100\% compliance? Infect Control Hosp Epidemiol; 18: 205-8.

Weber, DJ. Rutala, WA. (2001). Lessons from outbreaks associated with bronchoscopy. Infect Control Hosp Epidemiol; 22: 403-8.

Wenzel, RP. \& Edmond, MB. (2005). Patient-to-patient transmission of hepatitis C virus. Ann Intern Med; 142: 940-1.

Wilcox, MH.; Fawley, WN; Wigglesworth, N. et al. (2003). Comparison of the effect of detergent versus hypochlorite cleaning on environmental contamination and incidence of Clostridium difficile infection. J Hosp Infect; 54: 109-14.

Woods DE. (1987). Role of fibronectin in the pathogenesis of Gram-negative bacillary pneumonia. Rev Infect Dis; 9 (Suppl 4): S386-90. 


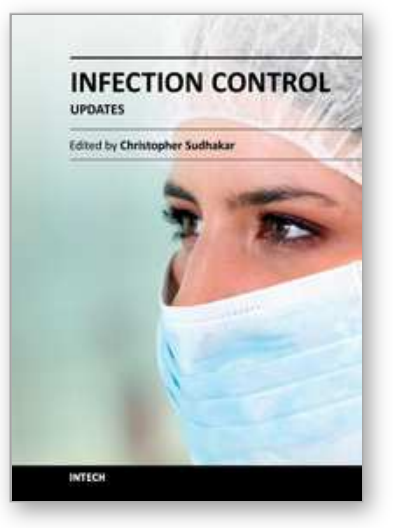

\author{
Infection Control - Updates \\ Edited by Dr. Christopher Sudhakar
}

ISBN 978-953-51-0055-3

Hard cover, 198 pages

Publisher InTech

Published online 22, February, 2012

Published in print edition February, 2012

Health care associated infection is coupled with significant morbidity and mortality. Prevention and control of infection is indispensable part of health care delivery system. Knowledge of Preventing HAI can help health care providers to make informed and therapeutic decisions thereby prevent or reduce these infections. Infection control is continuously evolving science that is constantly being updated and enhanced. The book will be very useful for all health care professionals to combat with health care associated infections.

\title{
How to reference
}

In order to correctly reference this scholarly work, feel free to copy and paste the following:

Hans Jørn Kolmos (2012). Health Care Associated Infections: Sources and Routes of Transmission, Infection Control - Updates, Dr. Christopher Sudhakar (Ed.), ISBN: 978-953-51-0055-3, InTech, Available from: http://www.intechopen.com/books/infection-control-updates/sources-and-routes-of-infection

\section{INTECH}

open science | open minds

\author{
InTech Europe \\ University Campus STeP Ri \\ Slavka Krautzeka 83/A \\ 51000 Rijeka, Croatia \\ Phone: +385 (51) 770447 \\ Fax: +385 (51) 686166 \\ www.intechopen.com
}

\author{
InTech China \\ Unit 405, Office Block, Hotel Equatorial Shanghai \\ No.65, Yan An Road (West), Shanghai, 200040, China \\ 中国上海市延安西路65号上海国际贵都大饭店办公楼 405 单元 \\ Phone: +86-21-62489820 \\ Fax: $+86-21-62489821$
}


(C) 2012 The Author(s). Licensee IntechOpen. This is an open access article distributed under the terms of the Creative Commons Attribution 3.0 License, which permits unrestricted use, distribution, and reproduction in any medium, provided the original work is properly cited. 